\section{MODERN MILITARY BULLETS: A STUDY OF THEIR DESTRUCTIVE EFFECTS.}

BY ARTHUR KEITH, M.D. ABERD., F.R.C.S. ENG.';

JOINT LECTURKR IN ANATOMY AND CURATOR OF'THE MUSEUM, LONDON HOSPITAL MEDICAL COLLEGE;

AND

HUGH M. RIGBY, M.B., B.S. LoND., M.R.C.S. ENG., SURGICAL REGISTRAR TO THE LONDON HOSPITAI.

IN the already extensive literature ${ }^{1}$ dealing with modern military bullets and the wounds which they produce it is difficult to obtain any clear idea of the relative amount of destruction caused by each. The experiments which we are about to record seem to us to be peculiarly fitted for a time like the present, in the midst of a great war between civilised nations in which the relative value and destructive power of each kind of bullet will unfortunately be tested to the uttermost. Our experiments were made before the present war broke out and our chief object was to see how far the condemnation of our modified Service bullets (the Dumdum and Mark IV.', see Fig. 1, $a, b, c$ ) by continental experts was justified; but as we tested at the same time our Service bullet (Mark II.) against the Mauser-the official bullet of the Boers-that part of our work will have the greatest present interest. Nothing gave us greater satisfaction than to learn that neither our Mark IV. nor our Dum-dum bullet were to be used in South Africa.

In the preparation of specimens for the London Hospital Medical College Museum to illustrate the nature of bullet wounds one of the bullets to receive our chief attention was the "Dum-dum." Readers are doubtless aware of the unenviable notoriety which this particular bullet has already gained, the continental experts from von Bruns downwards having, without a single exception, characterised it as " unnecessarily cruel, detestable, and inhuman." At the Peace Conference which met at The Hague last summer the continental members unanimously condemned this bullet, the representatives of Fingland and the United States being the sole dissentients. The Peace Conference was largely influenced in their decision by von Bruns's experiments. In a recent terse and vigorous article Professor Ogston has shown that a fundamental error existed in these experiments, since the bullet used by von Bruns was not the ordinary service Dum-dum but a very exaggerated form known as the "elephant bullet." An examination of von Bruns's original paper shows that the bullet he used had five millimetres of lead projecting unmantled in front, whereas our service bullets have never more than one millimetre exposed. But in spite of the defence of the Dum.dum bullet so ably maintained by Professor Ogston the fact remains that it is immensely destructive. Every weapon of war is "cruel, detestable, and inhuman," but whether the Dam-dum bullet is unnecesarily so is rather a question for military experts than for medical men. In our experiments we have made use of the service rifles and ammunition of this country and of Germany as we particularly wished to compare the relatively destructive power of the Mauser bullets which have been adopted by the South African Republics and those which are in use in the British army. Further, we also tested the various forms of revolver ammunition used by the Boers and by the British-viz., the Webley service revolver with solid and "man-stopping" bullets and the Mauser pistol with solid and hollow-nosed bullets.

I The best introruction to this subject is Mr. Victor Horsley's lecture at the Royal Institution, April 6th. 1894, "The Destructive Effects of Projectiles." See also "Wounds in War," by Lieut.-Col. W. F. Stevenson (1897); Professor von Bruns's “ Inhumane Kriegs-Geschosse," Archiv für Klinische Chirurgie, 1899, Band lvii.. pp. 602-607 (a condemnation of the Dum-dum bullet); "Ueber die Wirkung der neuesten Englischen Armeegeschosse," Tubingen, 1899 (a condemnation of Mark IV. bullet); "Erfets du Projectile du Nouveau Fusil de Petit Calibre," traduit par Projectile Cruxelles, 1894 ; "Etudes Expérimentales sur l'Action du Bucharest, 1894. "Les du Fusil Mannlicher," Dr. A. Demosthen, Vulnérante" ; "Les Projectiles des Armes de Guerre leur Action Onnerante, par H. Nimier et Ed. Laval, Paris, 1899; Professor Ged 's The Peace Conference and the Dum-dim Bullet," Brit. Address to the British Medical Association, THE LANCeT, August 3rd, 1895.
In order to forestall criticism of the methods adopted, especially the shortness of the range-viz., 20 metres-we would point out here that the destructive power of a bullet depends on two factors-(1) its momentum, and (2) its expansibility on impact. It will be seen from the following table, in which Mr. John Rigby has kindly worked out the velocity of the Mauser and Lee-Metford bullets, that the difference in momentum is for practical purposes negligible, the increased velocity of the Mauser being compensated for by the increase of weight of the Lee-Metford bullet.

TABLE OF Velocities.

\begin{tabular}{|c|c|c|c|c|c|}
\hline \multirow{2}{*}{\multicolumn{2}{|c|}{ Distance. }} & \multicolumn{4}{|c|}{ Velocity per second. } \\
\hline & & \multicolumn{2}{|c|}{ Mauser, 0.275 . } & \multicolumn{2}{|c|}{ Lee-Metford, 0.303 . } \\
\hline \multicolumn{2}{|c|}{ At muzzle } & $2345^{\circ}$ & feet & 2000 & feet \\
\hline,$\quad 10$ & yards & 2123 & ", & 1834 & $"$ \\
\hline$\Rightarrow 200$ & $"$ & 1934 & $"$ & 1680 & " \\
\hline,, 300 & , & 1762 & $"$ & 1534 & $"$ \\
\hline " 400 &, & 1602 & " & 1399 & $"$ \\
\hline$" 500$ & 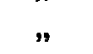 & 1453 & $"$ & 1278 & , \\
\hline$" \quad 600$ & , & 1317 &, & 1175 &, \\
\hline$" 700$ & $"$ & 1201 & , & 1087 & $"$ \\
\hline , 800 & , & 1104 & , & 1025 & $"$ \\
\hline$" 900$ & $"$ & 1032 & $"$ & 978 & $"$ \\
\hline$" 1000$ & ", & 981 & " & 934 & $"$ \\
\hline , 1100 & $"$ & 935 & " & 895 & $"$ \\
\hline " 1200 & ", & 893 & ", & 858 & , \\
\hline , 1300 & $"$ & 854 & ", & 825 & ", \\
\hline , 1400 & , & 819 & $"$ & 794 & $"$ \\
\hline " 1500 & ", & 786 & , & 764 & ", \\
\hline
\end{tabular}

From the above table it is obvious that the momentum of the Mauser bullet and the Lee-Metford bullet at any range is practically identical. Hence it follows that the difference in the wounds caused by each must depend upon the second factor-viz., the expansibility. The destructive power of any bullet is represented by the amount of force it can dispose of in its passage through the body, and the greater the expansibility the greater the force spent in the tissues and the greater the destruction produced. The ideal destructive bullet is one which expends all its force in the tissues on impact, and the modified Service bullet and the exaggerated Dum-dum used by von Bruns come wonderfully near perfection.

Perhaps a third factor in the destructive power of bullets is the corkscrew-like spin of the bullet round its axis of projection. The spin is slight in the Manser bullet and the Mark II. bullet (Figs. 1, $a$ and $d$ ), but it is very considerable when the mantle is open in front. In the soap wounds as also in clay wounds observed by $\mathrm{Mr}$. Victor Horsley, a spiral groove consisting of as many as five spiral turns may be seen in each bar of soap indicating the spin of the bullet Undoubtedly this spin is the immediate cause of much of the débris that occurs in wounds. Objections have been made to the comparison of results obtained in the cadaver with those obtained in living subjects. The living body is practically a system of compartments filled and distended with fluid, and hence intensely susceptible to the well-known explosive effects. We obviated that error as much as possible by selecting a subject in which the amount of fluid in the tissues seemed to us to represent the amount present in life, and, further, in order to be able to measure more accurately the exact amount of destruction caused we used a cadaver which had been preserved by the injection of a fluid containing 3 per cent of formal aldehyde, 6 per cent. of glycerine, 5 per cent. of carbolic acid, 25 per cent. of spirit, and 51 per cent. of water. In such a subject the tissues are rendered firm enough to allow a section of the wound to be made, and thus the amount and form of destruction to be accurately measured. The results obtained on such a subject tend to minimise rather than to magnify the destruction caused by the same bullets on the living subject - a fact which will, however, not alter the value of our comparative results. In order to standardise the destructive effects of bullets, as far as that is due to (1) their expansibility and (2) their spin we have used bars of ordinary yellow soap. This material we hare found the most suitable on which to measure the amount of substance or tissue displaced by a bullet in its 
FIG. 1.

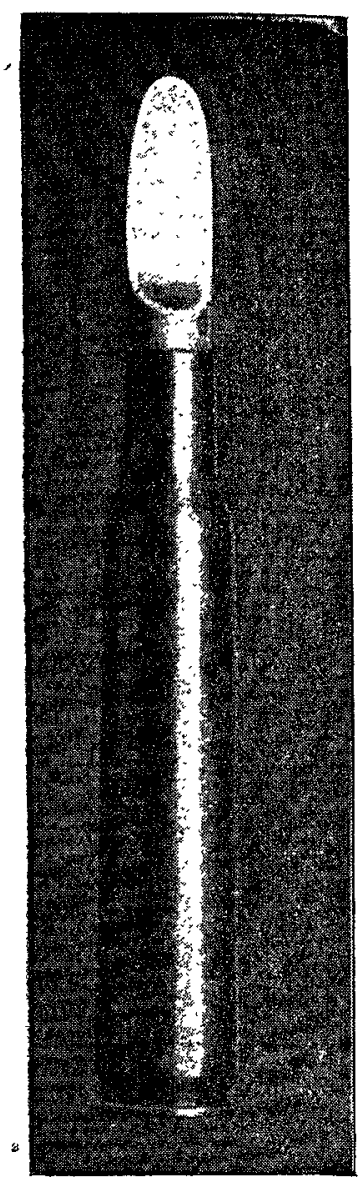

$a$

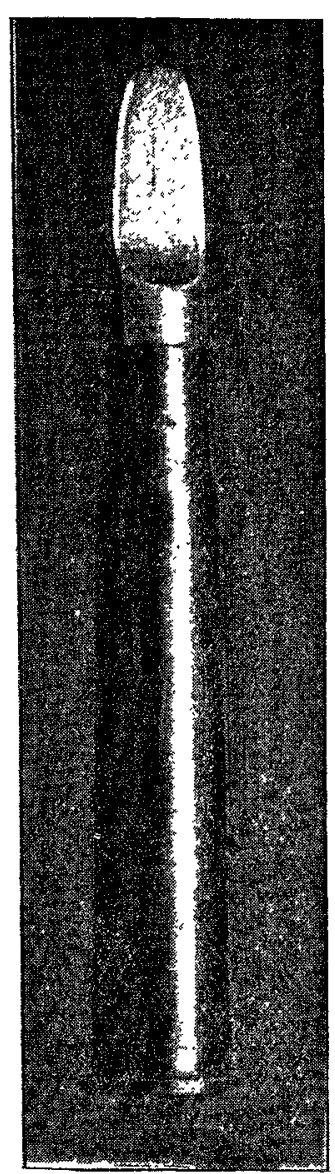

$b$

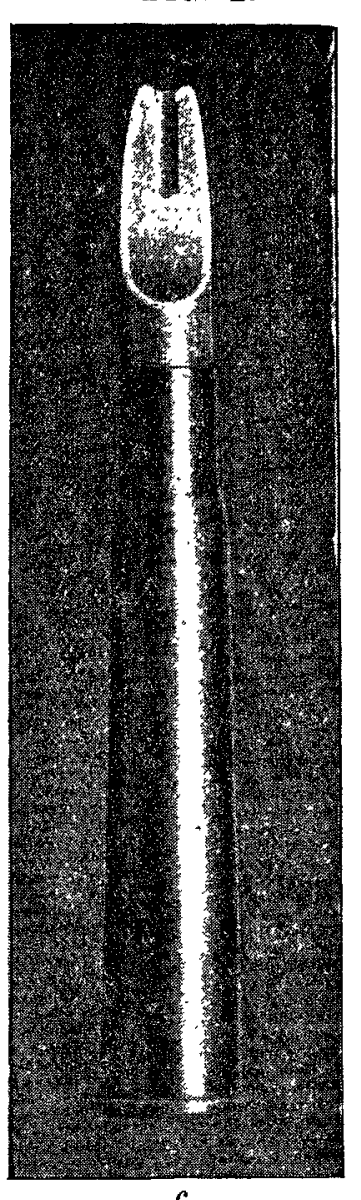

$c$

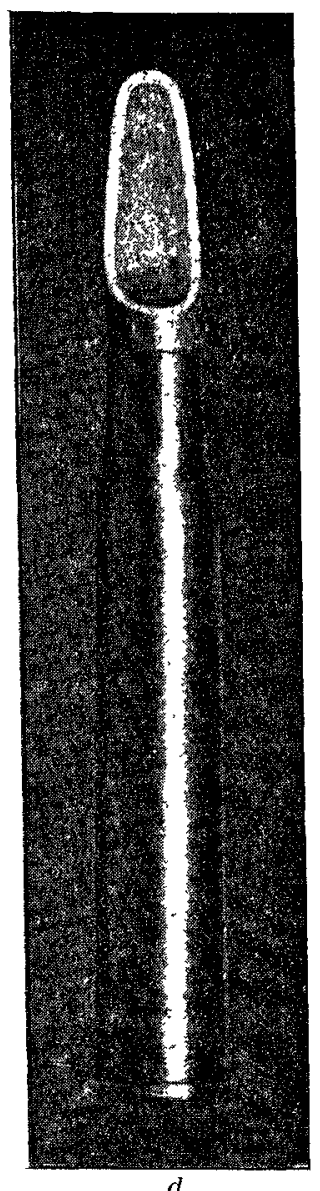

$d$

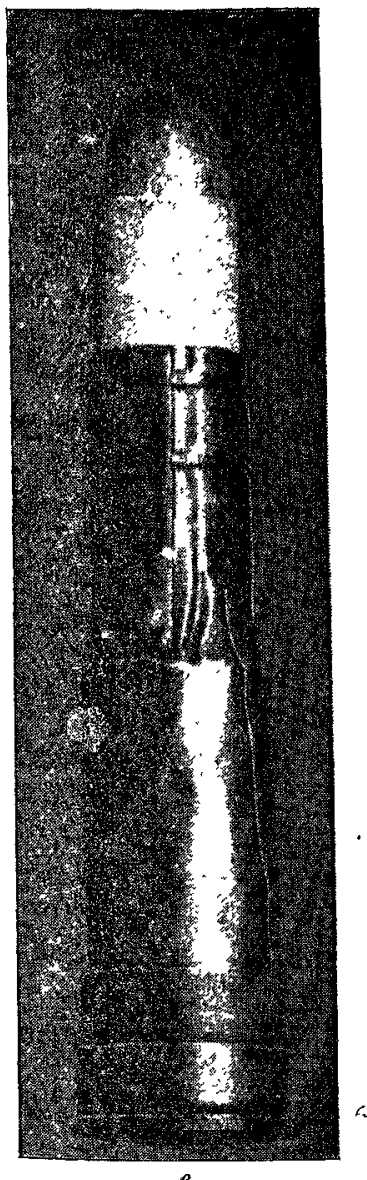

$e$

a, Mark II. bullet, in use by English in the present campaign. b, Dum-Aum bullet. c, Hollow-nosed or Mark IV. bullet. $d$, Mauser steel-mantled bullet, in use by the Boers in the present campaign. $e$, Martini-Henry bullet. The Mark II., the Mark IV., and the Dum-dum bullets all have a muzzle velocity of 2000 feet per second; each weighs 215 grains and is seven millimetres in diameter. The Mauser bullet has a muzzle velocity of 2345 feet per second.
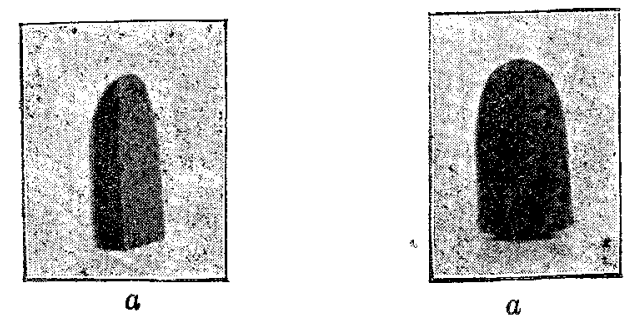

$a$

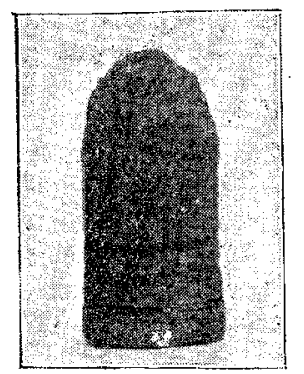

$c$
Fig. 2.
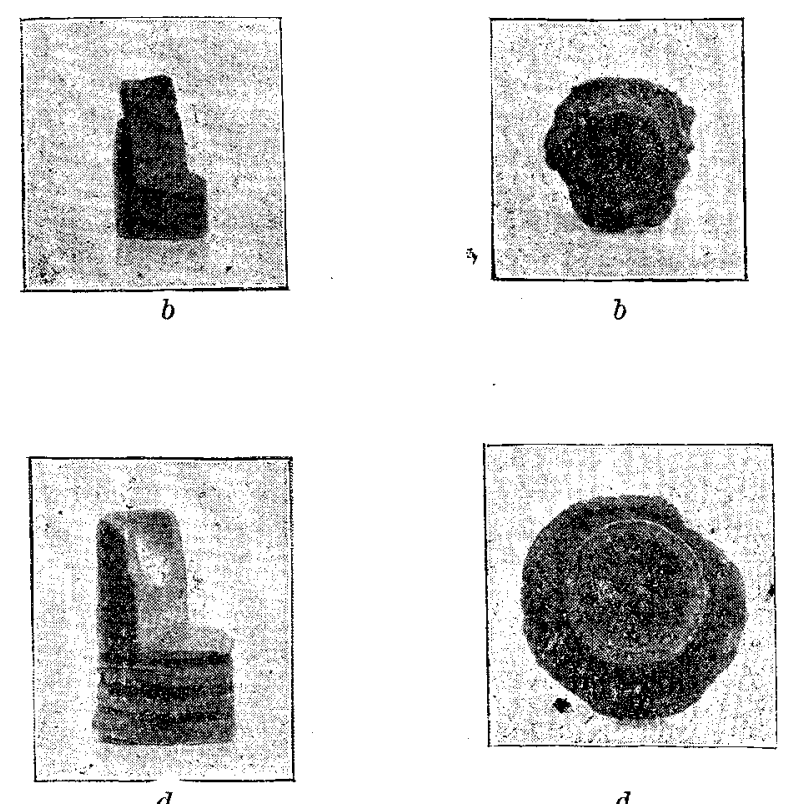

$d$

$a$, The Mauser pistol solid bullet. $a^{\prime}$, The same bullet after experiments. $b$, The Mauser pistol hollow bullet. $b^{\prime}$, The same bullet after experiments. $c$. The Webley revolver solid bullet. $c$, The same bullet after experiments. $d$, The Webley revolver hollow bullet. $d^{\prime}$, The same bullet atter experiments. The weight of the pistol bullet is 85 grains, the diameter 7.65 millimetres, anit the muzzle velocity 1400 feet per second. The weight of the solid revolver bullet is 265 grains and of the hollow revolver bullet 218 grains. In each case the diameter is $11 \cdot 43$ millimetres and the muzzle velocity 700 feet per second. 
course (Figs. 3 and 4). The peculiar physical properties made easily into a Dum-dum, and then the destructive effect of soap eliminate both the explosive effects obtained from is increased by threefold, but the increase in destructive fluid in compartments and the crushing effects seen in brittle effect is much greater in the Mauser.

substances such as bone, and only the path made by the bullet is represented. It is important to use in each experiment soap of the same consistency-i.e., containing the same quantity of water. We found that a Mauser bullet 0.275 diameter fired into a bar of soap at a distance of 20 feet $(6$ metres) produced a wound with a diameter of 28 millimetres, the area of the circle produced being therefore 784 square millimetres or 07 square metre. By using this measurement as a standard we have drawn up a table

In comparing the destructive effects of bullets on the human body three sharply differentiated types of wounds have to be distinguished : (1) pure flesh wounds ; (2) wounds in which bone is involved and crushing effects are produced; and (3) wounds in which the bullet has passed through a cavity with fluid contents-e.g., the capsule of the liver containing blood and hepatic substance, the medullary cavity of a long bone containing marrow, or the skull containing brain and blood. Further, it is important to recognise clearly that.

F゙IG. 3.

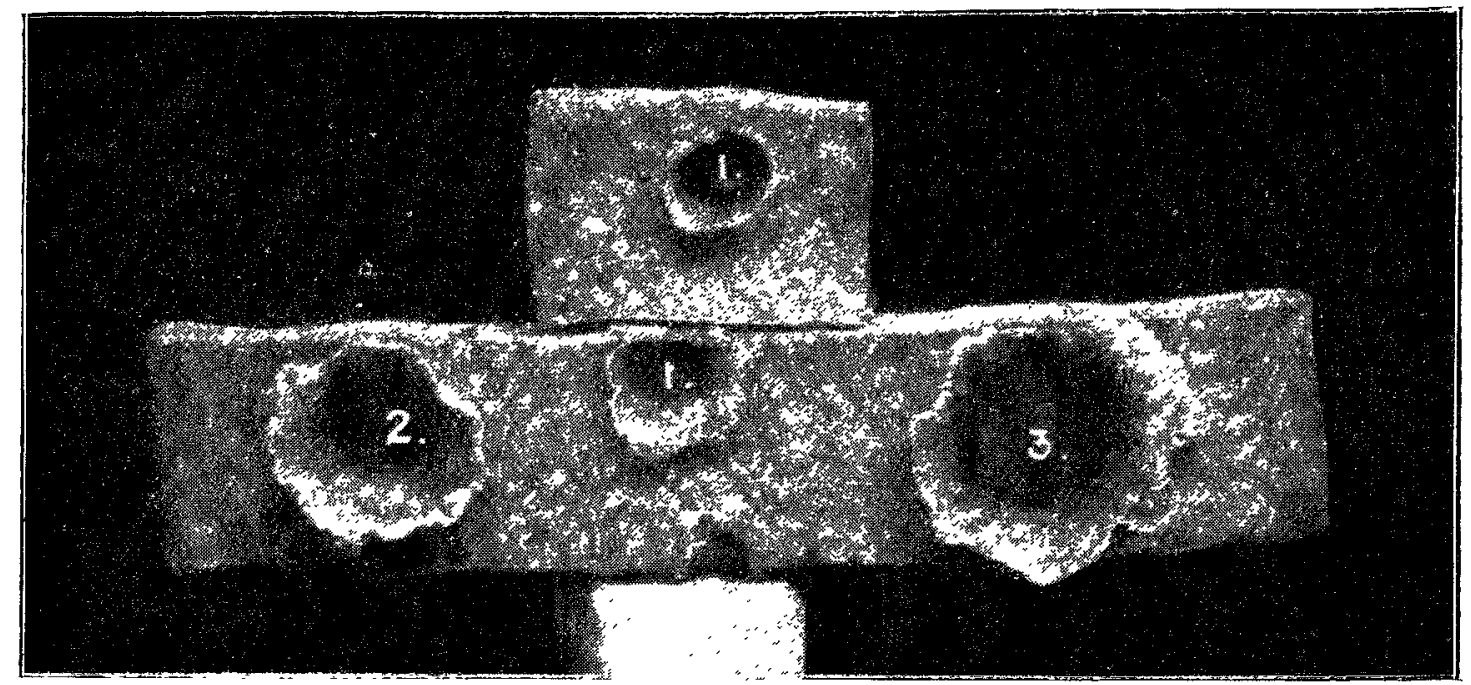

Exit wounds in a bar of soap made with-1, a sporting rifle ; 2, a Mark II. bullet; and 3, the Soudan form of Dum-dum.

Fig. 4.

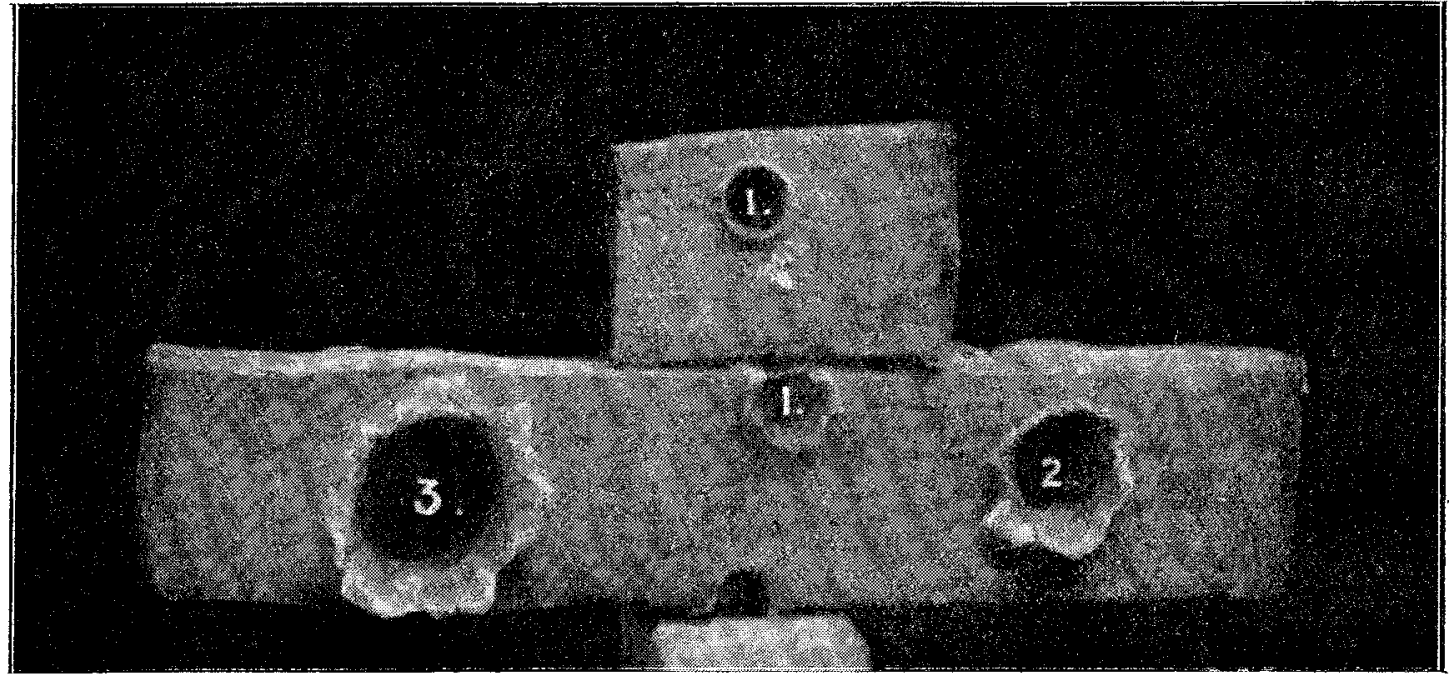

Showing the entrance wounds in the same bars.

estimated in terms of the Mauser effect as unit. The results are as follow :-

Wounds produced in Soap by Bullets fired at 6 metres.

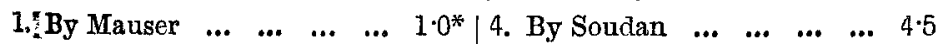

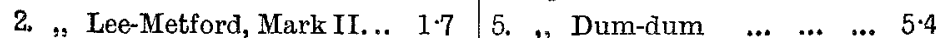

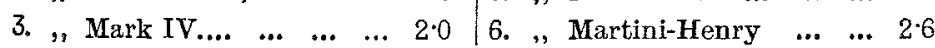
$* 1=$ unit $=784$ square millimetres.

Wound produced in Soap by Revolver Bullets fired at 5 metres.

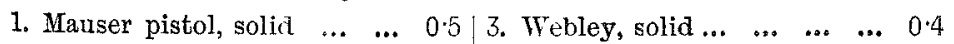

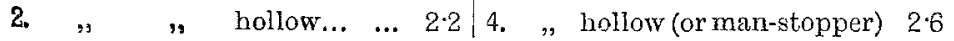
(Eee Figs. 1, 2, 3, and 4.)

In short, our Service bullet has a destructive effect more than half as much again as the Mauser-the bullet of the Boers; but it must not be forgotten that either may be neither the wound of entrance nor the wound of exit is any index to the amount of destruction wrought. One need only look at Figs. 7, 10, and 13 and examine the external effects of the Mark IV. and Dum.dum bullets to be convinced of this point, and yet observer after observer contents himself with stating the extent of the surface wounds as an index of the destructive power of the bullet used. Commonly the wound of exit is the larger, but in the hollow-nosed revolver bullets the entrance wound is four or five times larger than that of the wound of exit (Fig. 11).

An examination of the flesh wounds produced by the fully mantled Mauser and English service Mark II. and Mark IV. confirms the results obtained by those bullets in soap (Figs. 5, 6, and 7). If the destructive power of the Mauser be taken as the unit that of the Mark II. bullet is nearly twice and that of the Mark IV. is more than twice as great. Among our specimens we have unfortunately no pure flesh wounds made by the Dum-dum bullet, but judging from the results in parts where bore is concerned the effect would 
FIG. 5.

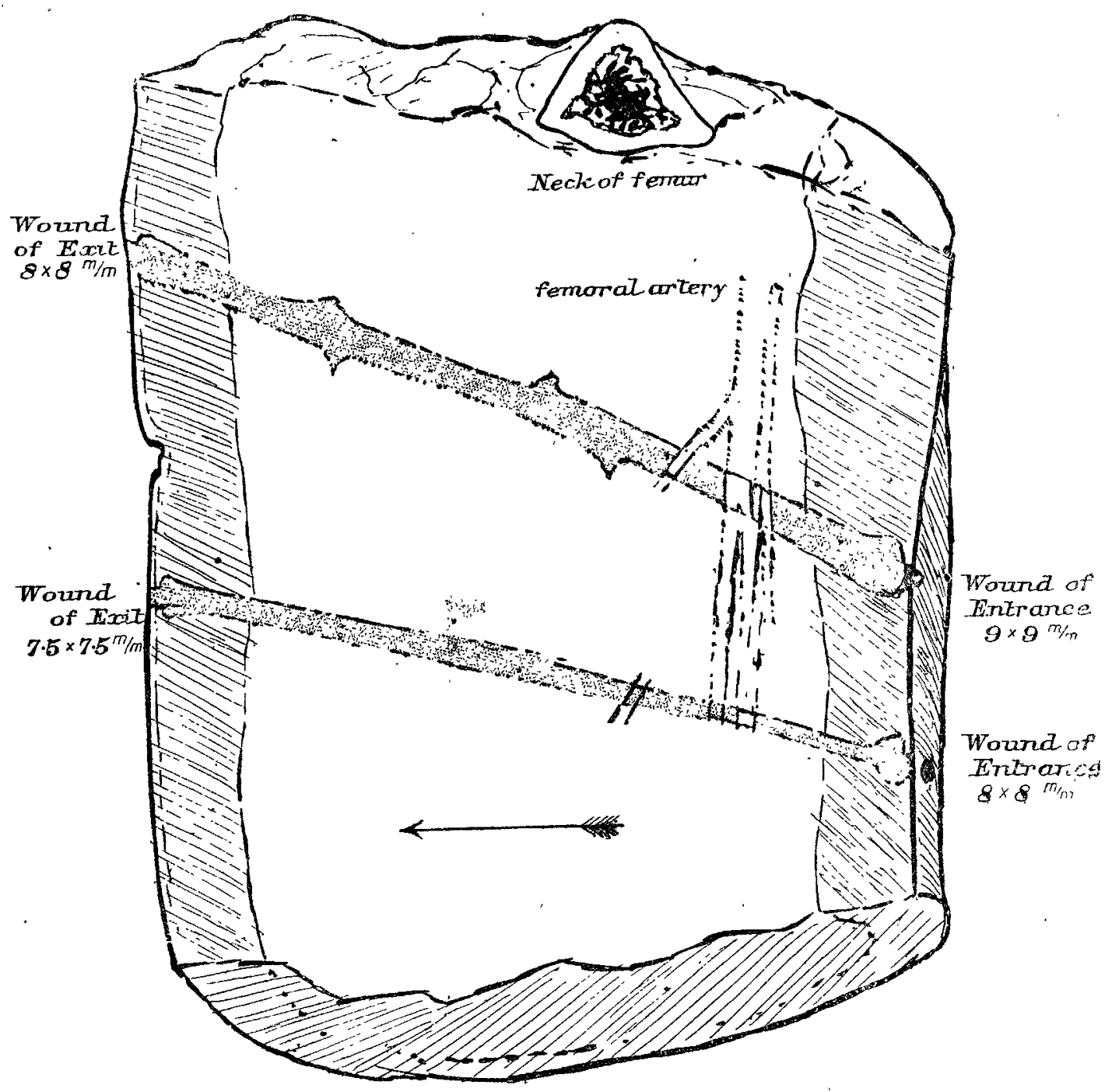

Inner aspect of thigh. Mauser bullet. Stipplèd lines show the tissues destroyed. Half natural size.

FrG. 6.

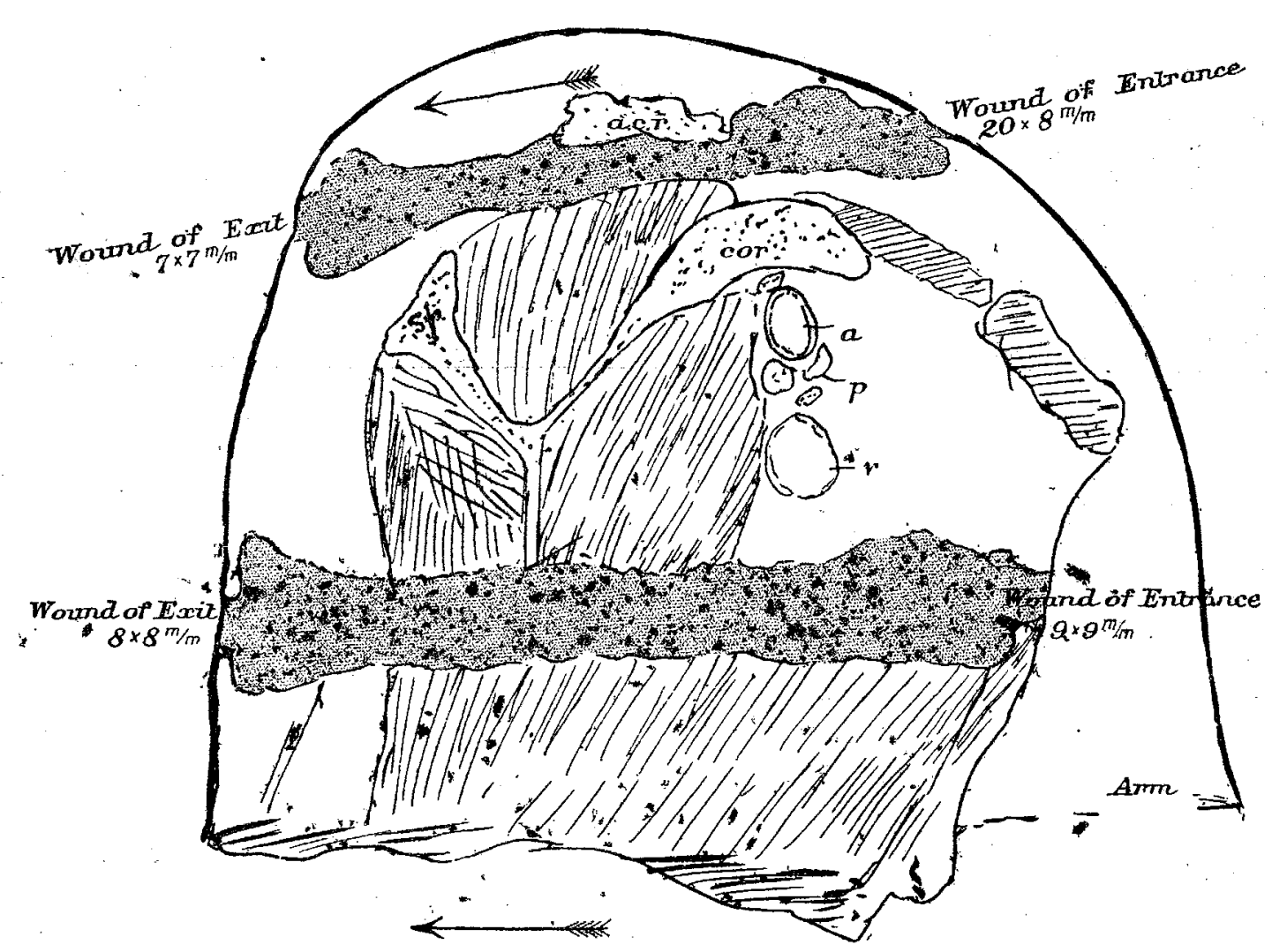

Inner aspect of left "shoulder. Mark II. bullet. Stippled lines show the tissues destroyed. aer., Acromion process; cor., coracoid process ; and sp., spinous process of the scapula. a, axillary artery; $v$, axillary vein; and $p$, brachial plexus. Rathor more than process ; and sp., 
probably be four or five times that of our unit. The large wound of entrance of the Mark II. shown on the left shoulder in Fig. 6 is quite uncommon.

The entrance and exit wounds of fully mantled bullets are almost invariably equal to the diameter of the bullet. Arterier, tendons, or nerves situated in the axis of projection are: cut through, but if outside that axis and yet in the destructive track of the bullet they are left practically uninjured. One of the best exanuples of this is seen in Fig. 10, where the Mark IV. bullet passed between the vena cava and the aorta, carrying away the vertebræ behind and yet leaving those vessels almost intact in the centre of the wound. A bullet travelling through flesh meets with so little resistance, the:particles moving aside so easily to let it pass, that it can unburden itself of but little energy and therefore work but wrought is infinitely greater and therefore the fatality doubly sure. The range for destruction of bone as compared with perforation of bone is a longer one for the English expansile bullets than for the continental fully mantled bullets, but at close ranges, although they work more damage than the fully mantled bullet, yet both are alike fatal to a limb if a large bone be struck. Professor von Bruns in his denunciation of the English expanding bullets seems to have overlooked the dire effects caused by older bullets such as the Martini-Henry.

In Figs. 8 and 9 are contrasted exactly similar wounds produced in the knee-joint by our present Service'bullet Mark II. and its predecessor, the Martini-Henry bullet. It will be noticed that the destruction wrought by the MartiniHenry bullet is infinitely the greater, as the experiments in

FIG. 7.

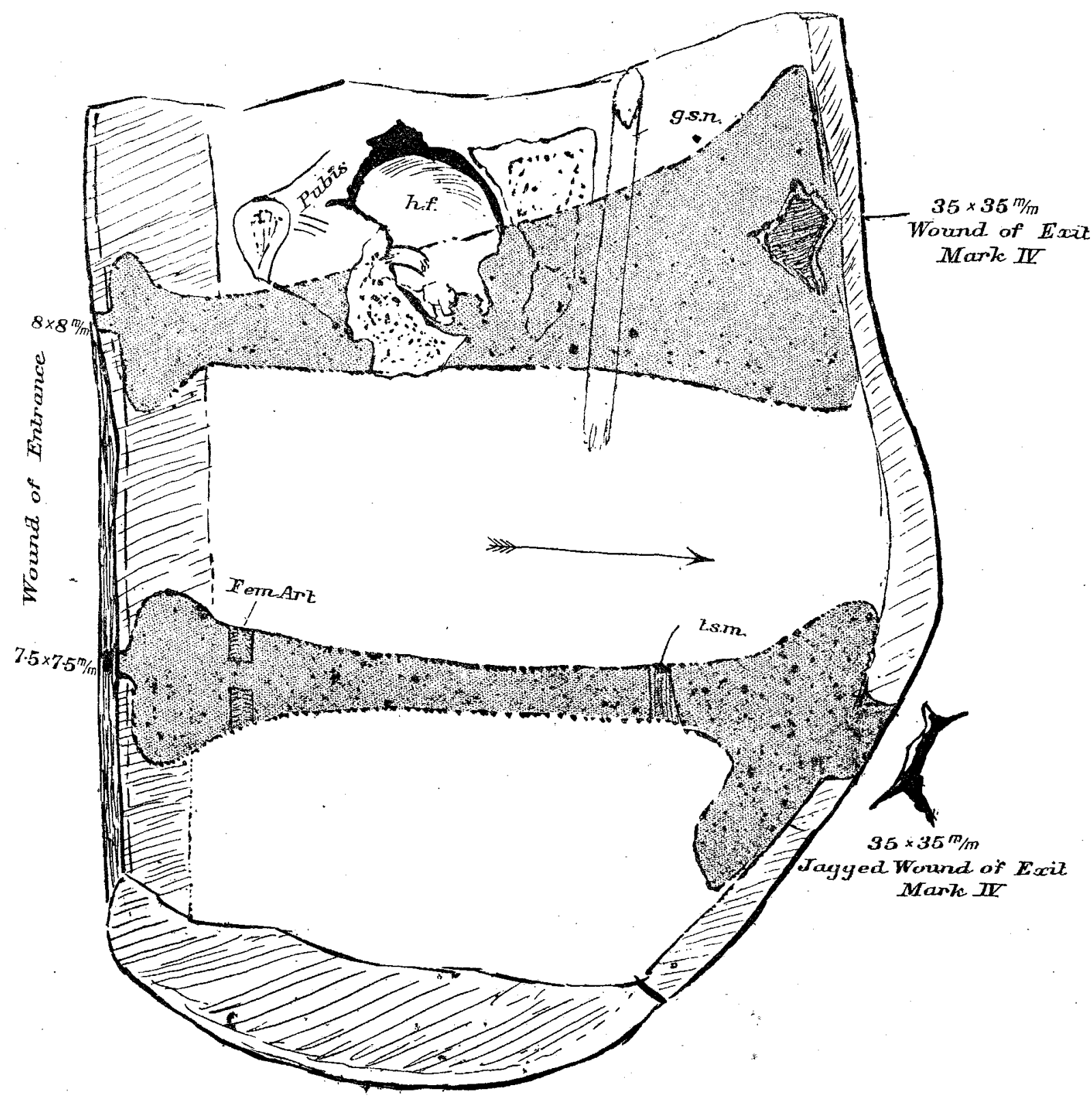

Inner aspect of right thigh. Mark IV. bullet. Stippled lines show the tissues destroyed. h.f., Head of the femux: gos.n., The great sciatic nerve. t.s.m., The tendon of the semi-membranosus muscle. Half natural size.

little destruction, unless it be expansile and moving with a wide spin. But the results are quite different when a bullet meets with a bone; it crashes into it like $a$ steamer into $a$ wide and thin ice-floe, carrying ever a wider and greater accumulation in front of it, until it bursts through and strews the fragments in all directions as it makes its exit in the softer and less resistant tissues beyond. Bone, unfortunately, is the dustbin in which the bullet's energy is spent. Professor Ogston is perfectly right when he says that it matters little which bullet is used if bone is struck. All the small-bore bullets, at high velocities, can rid themselves on bone of sufficient energy to work damage absolutely fatal to the future of a limb. The Drmdam bullet only differs from the others in that the destruction soap would lead us to expect. Although the Mark II. bullet entered straight in the line of the joint, and between the femur and tibia, yet the ends of both these bones are splintered and cracked.

We have taken a skiagram of the wound produced on the right shoulder by the Dum-dum bullet which showed remarkable injuries. The surgical neck of the humerus is carried away, the shaft of the bone is shivered to its middle, the scapula is fractured, the destruction spreading almost up to the apex of the axilla and down to the insertion of the deltoid, and yet the brachial plexns and the axillary artery and vein are left intact in the midst of a cavity full of crushed tissue. The wounds of entrance and exit, moxeover, are rent and torn. 
In Fig. 10 are seen the wounds produced in the abdominal the thigh by the solid bullets the Mauser pistol and the cavity by the Mark IV. bullet and the Dum-dum bullet. wound of the same bullet with a"hollow nose. The hollowThe hollow viscera, which were almost empty, were neatly nosed bullet " mushrooms" out and works about five times the perforated, the destruction becoming most marked when the amount of destruction, as one would; expect from the soap

FIG. 8.

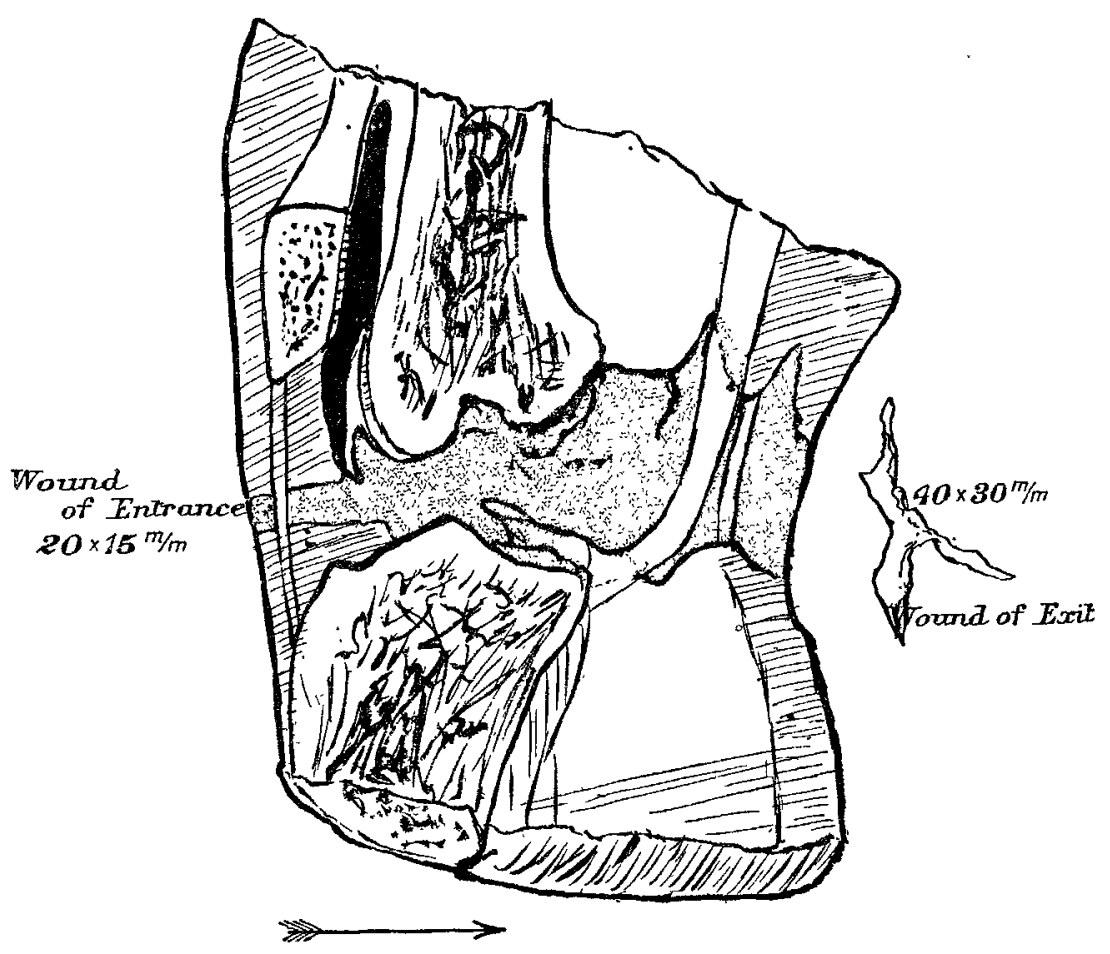

Knee-joint. Martini.Henry bullet. The stippled area shows the tissues destroyed. Half natural size,

FIG. 9.

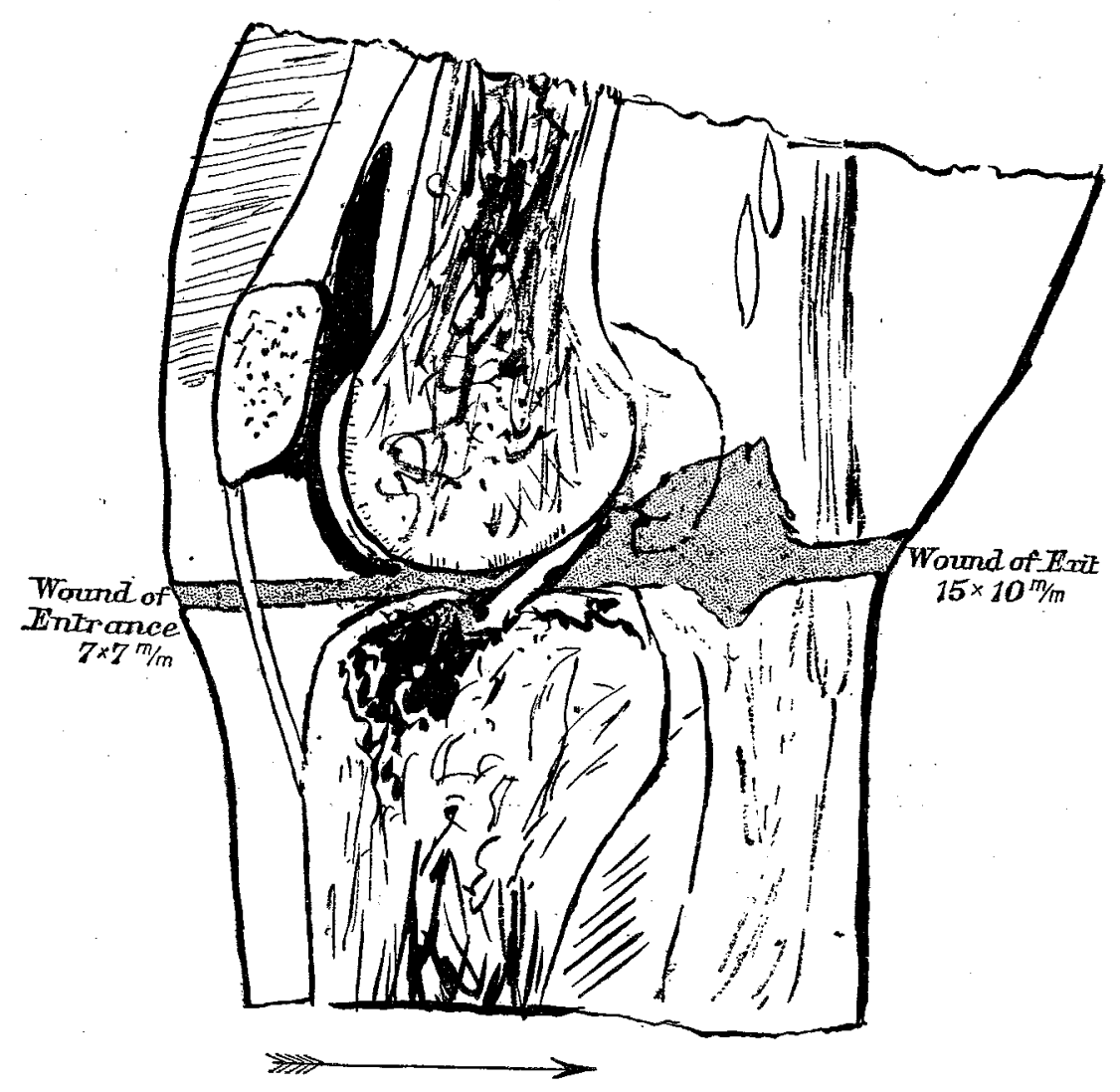

Knee-joint. Mark II. bullet. The stippled area shows the tissues destroyed. Half natural size.

spinal column was struck. The figure shows the amount of destruction that has taken place in the tissues, although it is on a much smaller scale than the other illustrations.

In Figs. 11 and 12 are shown the wounds produced in experiments. The hollow-nosed Webley Service revolver bullet (or so-called " man-stopper") exceeds in its effect the solid conical form in even a greater proportion.

Coming to a comparison of the third class of wounds 
FIG. 10.

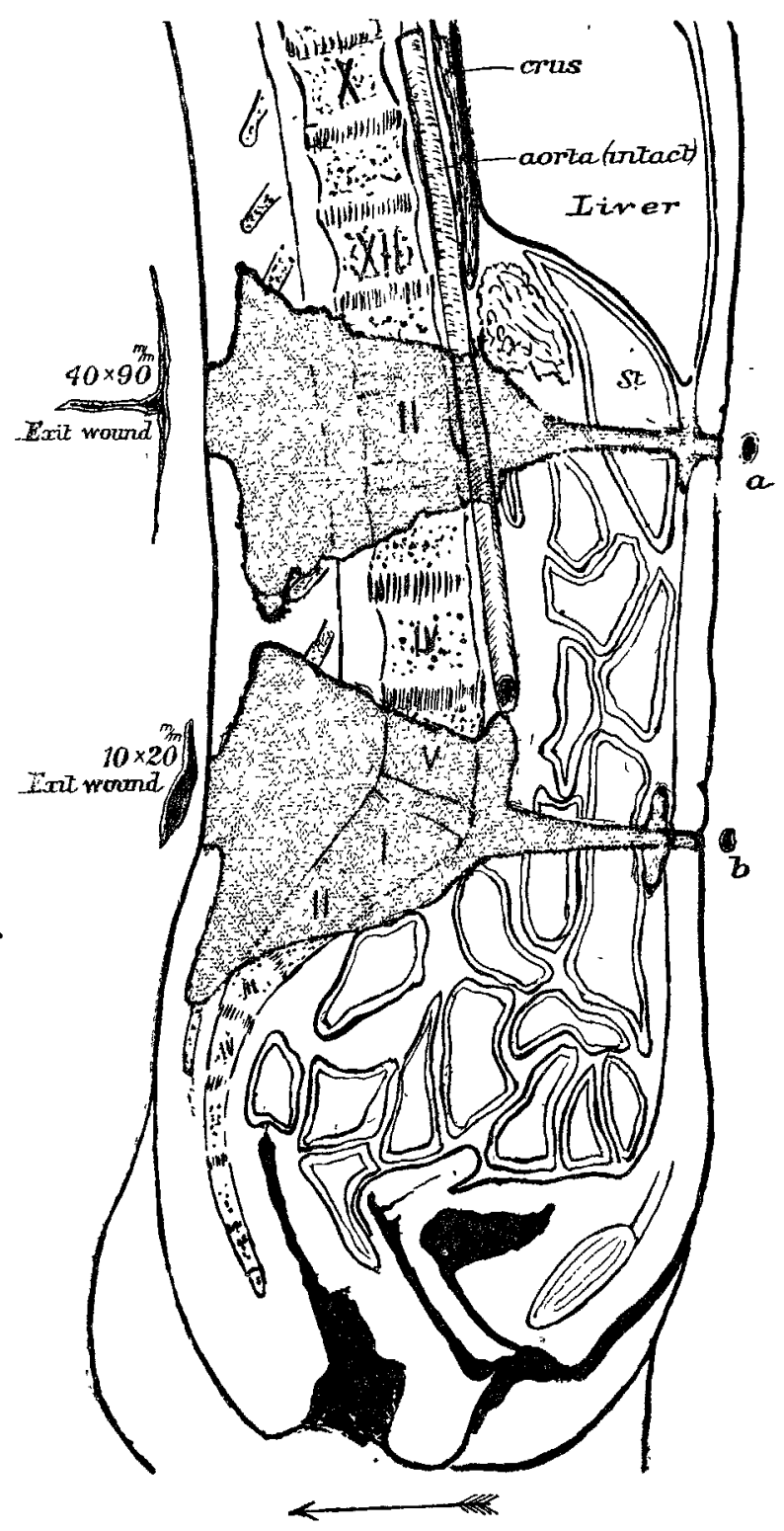

The trunk shot from the front by Mark IV. and Dum-dum bullets. c The stippled areas show the tissues destroyed. $a$, Entrance of Mark IV. bullet. $b$, Entrance of Dumdum bullet. In each case the entrance wound measured $7 . \times 7 \mathrm{~m} . \mathrm{m}$. Much reduced. produced by bullets of high velocity-viz., those marked by "explosive effects"-we come to a matter which has been made unnecessarily complicated. To obtain these effects, as is well known, the cavity need not be closed, but it must have its contents in a state of fluidity. When a bullet enters a closed compartment with fluid contents it comes to a medium in which it is able to unburden itself of its energy with great rapidity. In the summer-time, when the harbours of the north-east coast are crowded with fishing craft, one can see the explosive effect exemplified. If a little tug enter the shoal of boats gradually it can push its way through them, disturbing only the boats that touch its bows; but were it to steam wildly through them it would scatter them right and left, transferring the shock straight to the harbour wall. A bullet entering the brain at a low velocity drives the contents against the walls of the cranial cavity, but it has not momentum enough to drive them with a rupturing force. A flat-nosed bullet, like the Dum-dum, is able to transfer its momentum more rapidly and more effectually than a fully mantled bullet-hence its greater explosive effect. No bullet entering the skull with a momentum of less than 70 kilogrammetres will have energy enough to rupture the skull. Skulls undoubtedly vary as to the tension necessary to rupture them, but on the average, according to German experimenters, the above estimate is probably an accurate one. None of our modern bullets have that momentum beyond the 800 yards range, so that wounds showing explosive effects all occur within that limit.

The explosive range of the Dum-dum bullet is probably not greater than that of the fully mantled bullet since it loses its momentum more quickly. As far as explosive effects are concerned the fully mantled and opened-nosed bullets are unnecessarily effective, the Dum-dum being especially so. It is very important to remember that every bullet-wound is attended with a greater or less explosive effect. On firing at sections of the thigh we found that not only the marrow in the bones, but the clots in the arteries and veins were driven out at the cut ends. Even where a bullet travels slowly enough to neatly perforate a long bone the marrow is undoubtedly concussed and injured from end to end.

In Figs. 13, 14, and 15 are shown the explosive effects of the Dum-dum bullet on the head. The momentum of any of the modern military bullets in the first 100 yards of their course is sufficient to burst the skull open were it five times its normal strength. The effect produced in the head of the cadaver in this instance was to entirely blow off the roof of the skull and scalp, while the base of the skull was shattered and the brain was flung against the roof and round the walls of the lofty room in which the experiments were carried out. In order to study the explosive effects

FIG. 11.

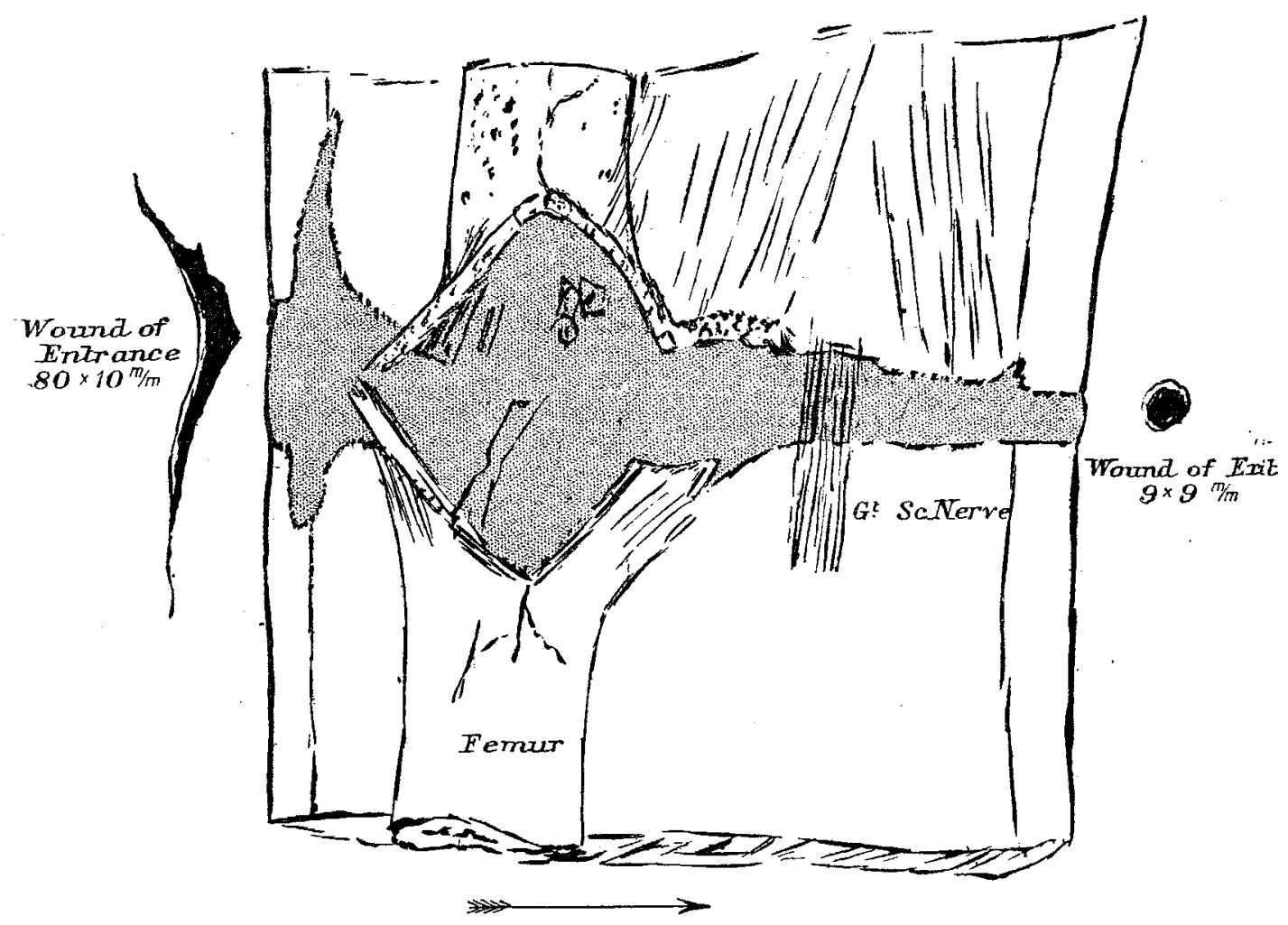

The thigh shot from front to back by hollow-nosed bullet from Mauser pistol. The stippled area shows the tissues destroyed.

(See Fig. $2 b$ also which shows such a bullet after firing) Rather more than half natural size. 
FIG. 12.

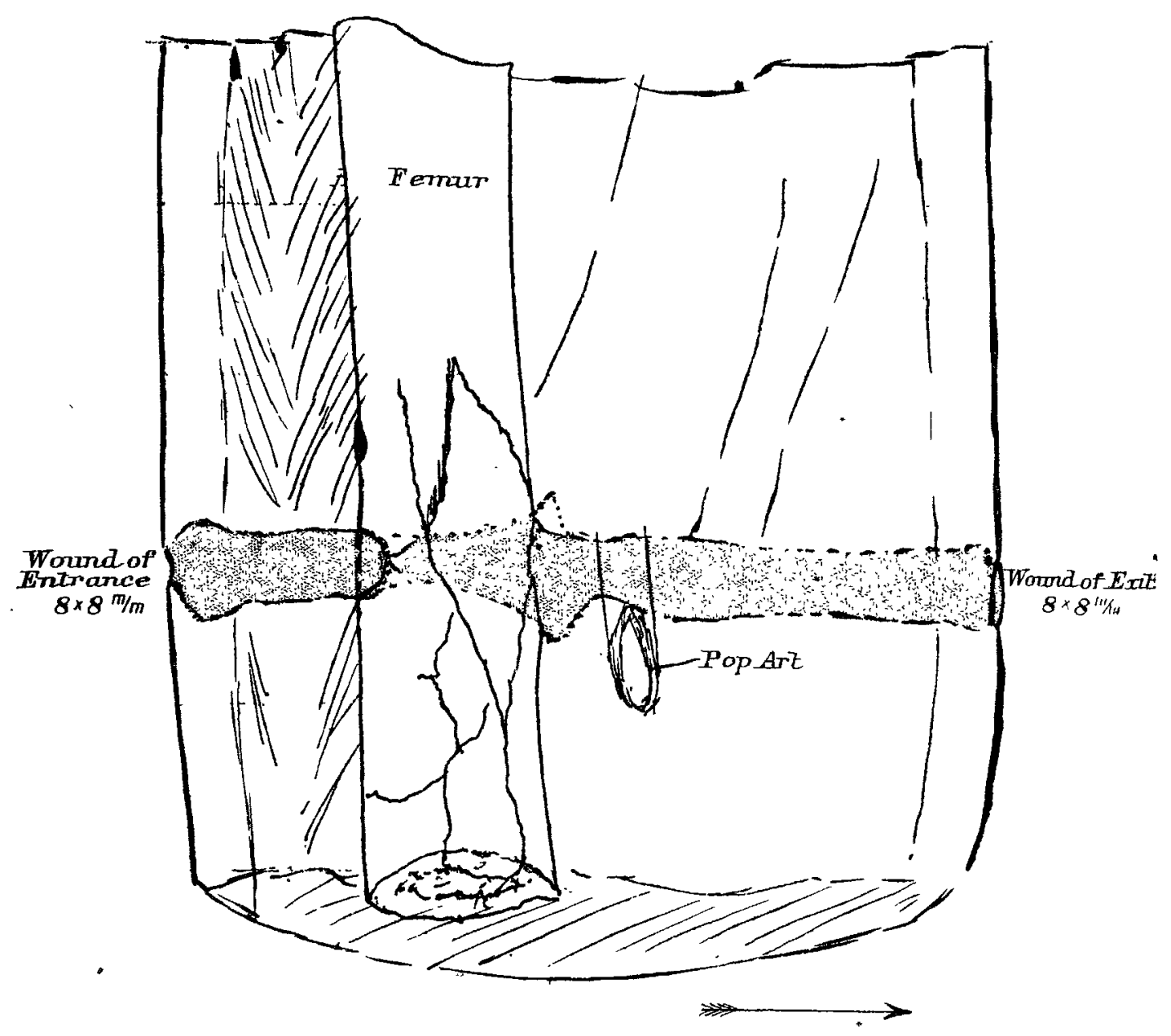

The thigh shot from tront to back by conical bullet from Mauser pistol. The stippled area shows the tissues destroyed. (See Fig. $2 a^{\prime}$ also which shows such a bullet after firing.) Rather more than half natural size.

of bullets we found plaster-of-Paris approaching its setting point to be the most satisfactory material. On filling a brown paper bag with the solution and waiting until it assumed the consistency of the brain we fired into it, and found the effects depended to some

FIG. 13.

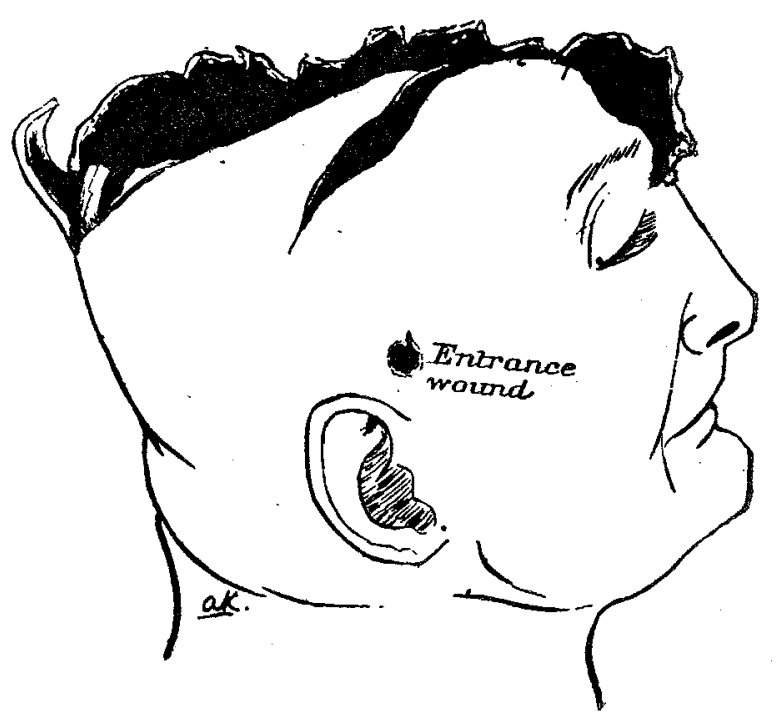

Crown of the head blown off, showing explosive effect of the Dum-dum bullet.

extent on the point struck. If the bag were struck fairly in the centre of its contents the whole mass was scattered and shattered, but if near the side then the larger moiety which acted as a fulcrum remained in position, the maller being blown off. This also holds true of the skull, complete explosive effects only occurring when it is struck near the centre. If the plaster were enclosed in a tin box and wrapped tightly with bandages it. was possible to obtain cavities showing the explosive effects and lines of force exerted. We filled skulls with such plaster and wisped them tightly in bandages. In Fig. 15 are shown the effects which we obtained with the Dum-dum and the Mark II. bullets. These specimens were prepared simply to illustrate, for medical students, the explosive effects of the bullets. In Fig. 16 are shown the wounds of exit of the Mauser bullet, the Mark II. bullet, and the Dum-dum bullet on skulls which were filled with paraffin wax. They show the same effect as found in soap, and the advantage to soldiers of brains giving a similar physical reaction.

To sum up, we find that the destructive effects of the Mark II. bullet, the Mark IV. bullet, and the Dum-dum bullet stand to the Mauser in the ratio of $1 \cdot 7,2$, and 5.4 to 1 . But this result applies mostly to flesh wounds, the bone-destroying and explosive tendencies of all, and especially of the open-nosed, bullets being unnecessarily great. We agree with Professor Ogston that von Bruns has overstated the case against the English open-nosed bullets. In the first place, the Dum-dum bullets which he used were much exaggerated forms; secondly, the wounds which he figures in his papers dealing with the effects of the Dum-dum bullet and the Mark IV. beillet were such as we have been unable to produce; and thirdly, the wounds are greatly exaggerated from the fact that dried and wizened legs of cadavers were mostly used. Bullets are meant to kill; when they fail and only wound, it is better that they should produce an effect sufficient to temporarily disable without causing permanent damage, but vinfortunately no modern bullet has yet attained to such perfection.

In conclusion, we would express our thanks to Messrs. $\mathbf{E}$. and J. Rigby for their kindness in providing us with the necessary firearms and bullets, and also to Sergeant William Duncan and Mr. Hilliard for their valuable help. 
FIG. 14.

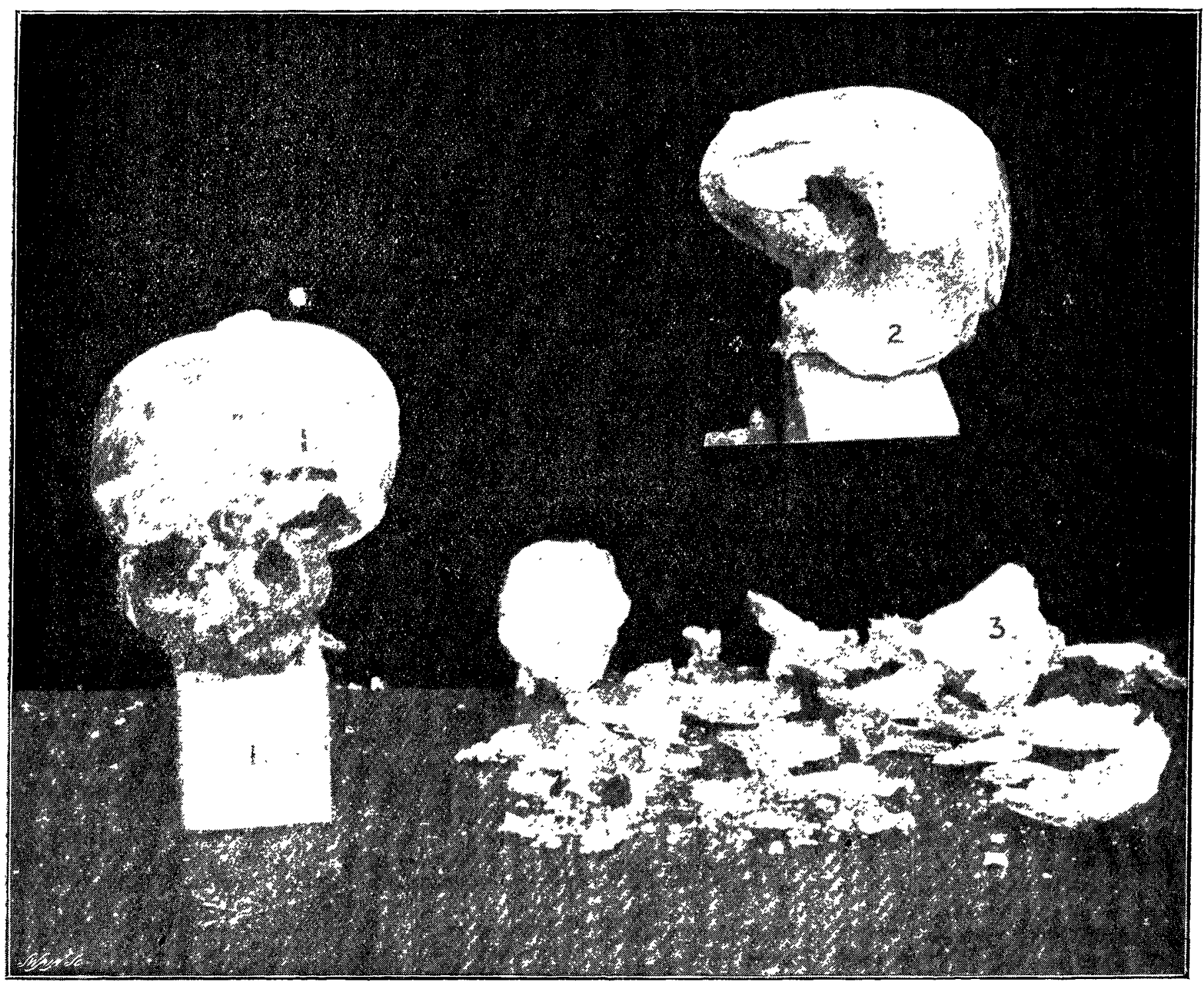

Shows the result of firing into skulls filled with plaster-of-P $P_{\text {ris }}$ about to set. Skulls 1 and 2 show respectively the wounds of entrance and exit made by a Mark II. bullet. 3 is placed on the remnants of a skull fired into with a Dum-dum bullet.

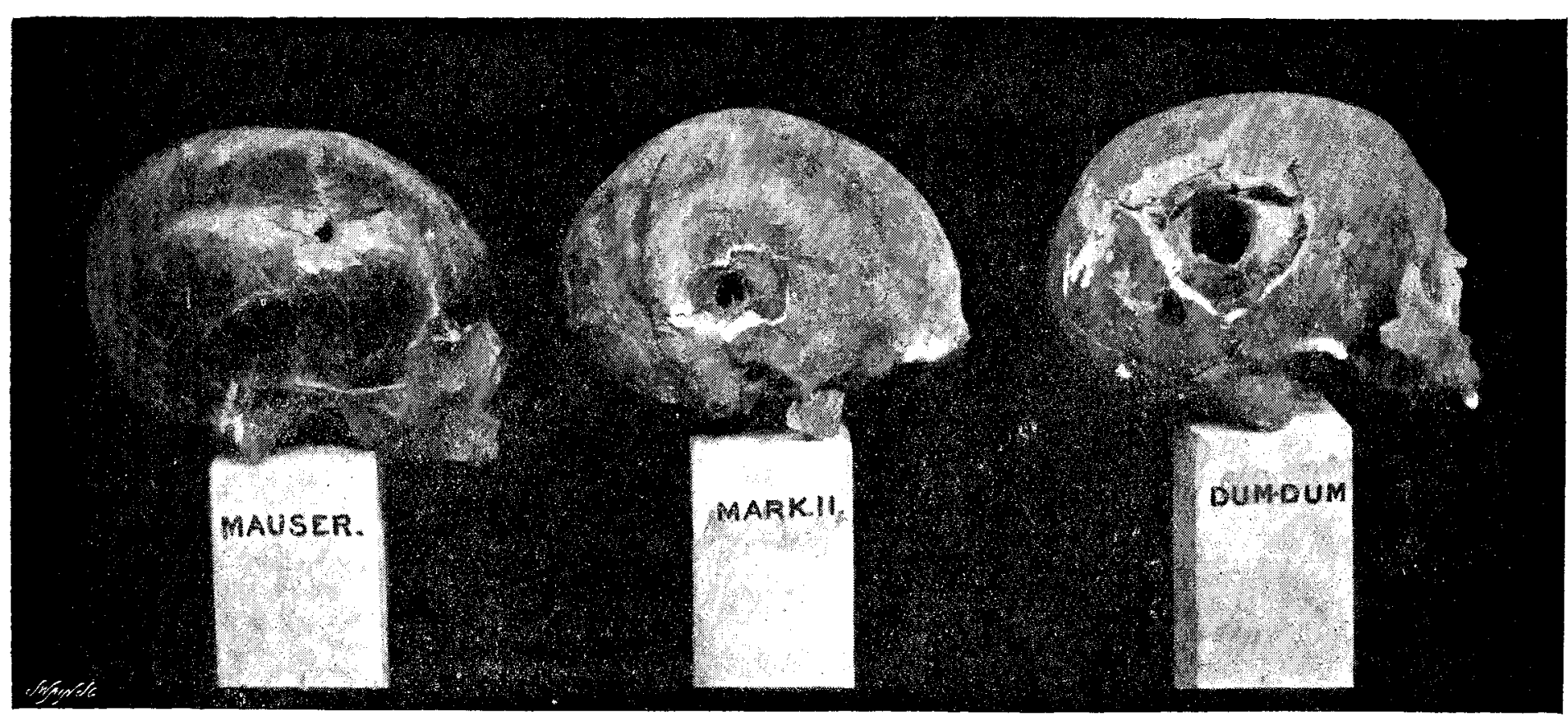

Shows the result of firing into skulls lilled with paraffin wax, using Mauser, Mark II., and Dum-dum bullets. 